\author{
O rest Kuntyi
}

\title{
MORPHOLOGY OF A DISPERSED TELLURIUM ELECTROCHEMICAL DEPOSITION IN APROTIC SOLVENTS
}

\author{
Lviv Polytechnic National University, \\ 12 Bandera str., 79013 Lviv, Ukraine \\ Kunty@polynet.Iviv.ua
}

Received: J une 2, 2007

\begin{abstract}
The electrolysis of $\mathrm{TeCl}_{4}$ solutions in dimethylsulfoxide, dimethylformamide and acetonitrile using soluble tellurium anodes has been investigated. At $313 \mathrm{~K}$ in $0.05 \mathrm{M} \mathrm{TeCl}_{4}$ over graphic undercoat the formation of compact tellurium deposit took place at cathode potentials less than $1.0 \mathrm{~V}$ and formation of dispersed deposit - at values more than $1.25-1.5 \mathrm{~V}$. Using the results of SEM researches it has been established that dispersed tellurium formed conglomerates consisting of intergrown lobes and knurls with the thickness $0.3-0.1 \mu \mathrm{m}$.
\end{abstract}

Keywords: disperse tellurium, morphology, electrolysis, aprotic solvents

\section{Introduction}

For the last decade electrochemistry of tellurium and tellurides in the medium of organic solvents [1-3] has been of great interest. Electrochemically such medium is more stable in comparison with aqueous solutions and gives possibility to reduce metals at high cathode potentials without electrode by-processes. Moreover, salts hydrolysis is absent in aprotic solvents, so metals may be deposited there, in contrast to aqueous solutions where such deposition is impossible. These advantages of nonaqueous medium favour the deposition of high pure metals, which is very important for semiconductor materials [4]. This work deals with the investigation of cathode deposition of dispersed tellurium in organic aprotic solvents and continues systematical studies of metal electrochemistry in nonaqueous medium [5-7].

\section{Experimental}

Tellurium has been deposited electrochemically in 0.01-0.1 molar solutions of $\mathrm{TeCl}_{4}$ in dimethylsulfoxide (DMSO), dimethylformamide (DMF) and acetonitrile (AN) in hydrostatic mode within the temperature range of 293-
$333 \mathrm{~K}$ at $\mathrm{E}=$ const. IPC-Pro potentiostate has been used and electrolytic potential has been measured by comparing chloride-silver electrode. $\mathrm{TeCl}_{4}$ has been synthesized by interaction between gaseous chlorine and grinded monocrystals at heating [8]. Experiments have been carried out in temperature-controlled glass electrolyzer with volume of $50 \mathrm{dm}^{3}$ using bulk anode made of tellurium monocrystals. Electrochemical deposition has been conducted over the polished front surface of graphite rod with diameter of $6 \mathrm{~mm}$. Then cathode tellurium, without being removed from an undercoat, has been rinsed consecutively with corresponding solvent and isopropanol. Tellurium has been investigated with REMMA-102-02 scanning microscope after drying at $323 \mathrm{~K}$.

\section{Results and Discussion}

The obtained results show the possibility of electrochemical deposition of compact tellurium (films) and dispersed tellurium of high purity in $\mathrm{TeCl}_{4}$ solutions in DMSO, DMF and AN. At the same time the morphology of metal film, as well as dispersed cathode metal, essentially depends upon nature of aprotic solvent (Figs. 1-3).

Compact tellurium is deposited at low cathode potentials in DMSO solutions. Submicron particles of pyramidal configuration are structural components of the deposit forming relatively compact packaging (Fig. 1a). The increase of cathode potential results in the following morphologic evolution of cathode deposit. At first a peculiar splicing of structural components takes place. The tellurium film becomes smooth and even glittering. This fact may be explained by cathode polarization caused by high electro-donor properties of DMSO molecules and presence of $\left[\mathrm{Te}(\mathrm{DMSO})_{n}\right]^{4+}$ stable solvates in the solution. The transition state between compact and dispersed deposit is shaggy surface with knurls (Fig.1b). The further increase of cathode potential results in the formation of dispersed deposit with developed surface (Fig. 1c). Such type of deposit has no well-defined structural hierarchy. 

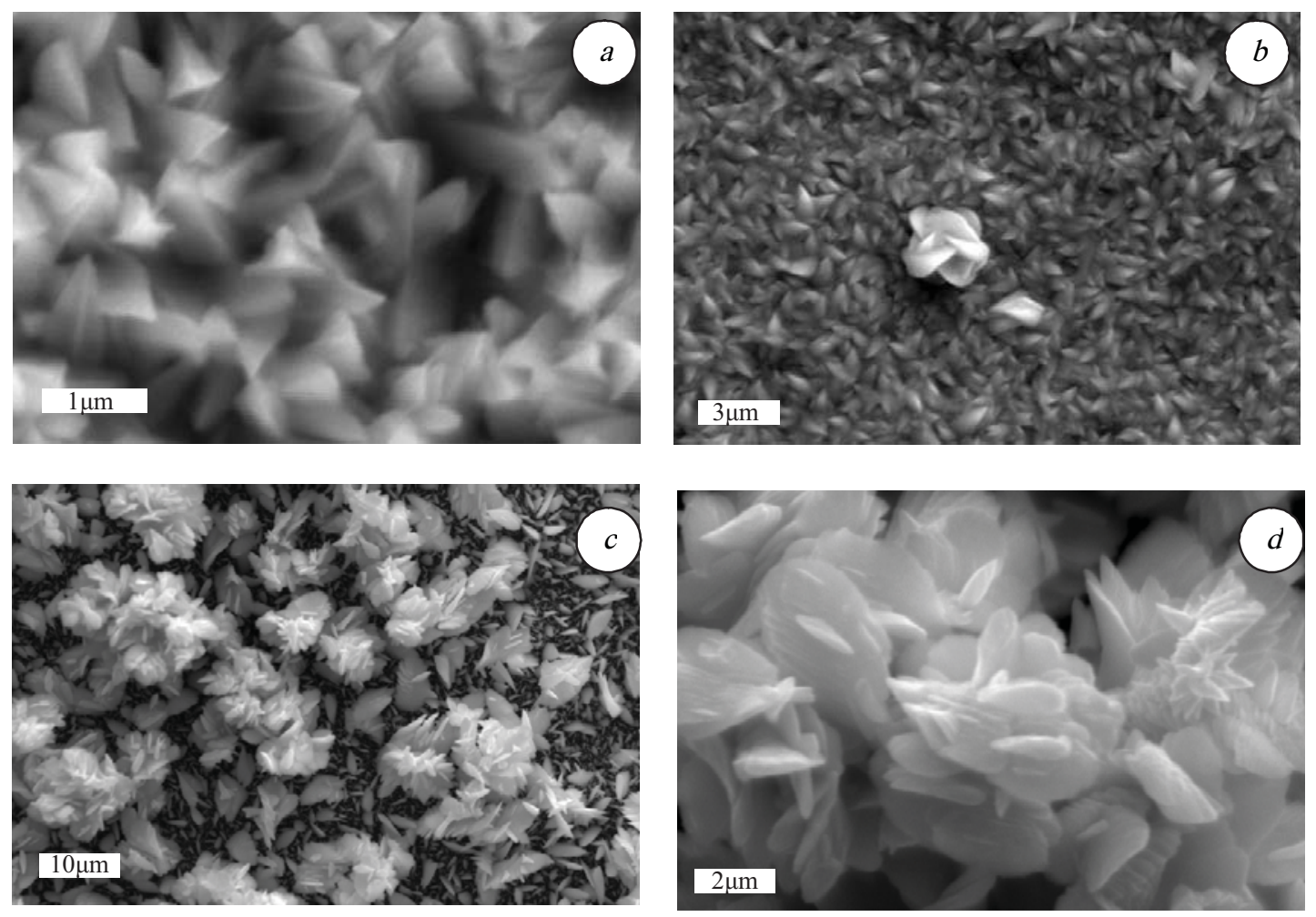

Fig. 1. SEM image of cathode tellurium obtained in $0.05 \mathrm{M} \mathrm{TeCl}_{4}$ in DMSO at $313 \mathrm{~K}$ and potentials (V): -0.5 (a); -1.0 (b); -1.25 (c, d)
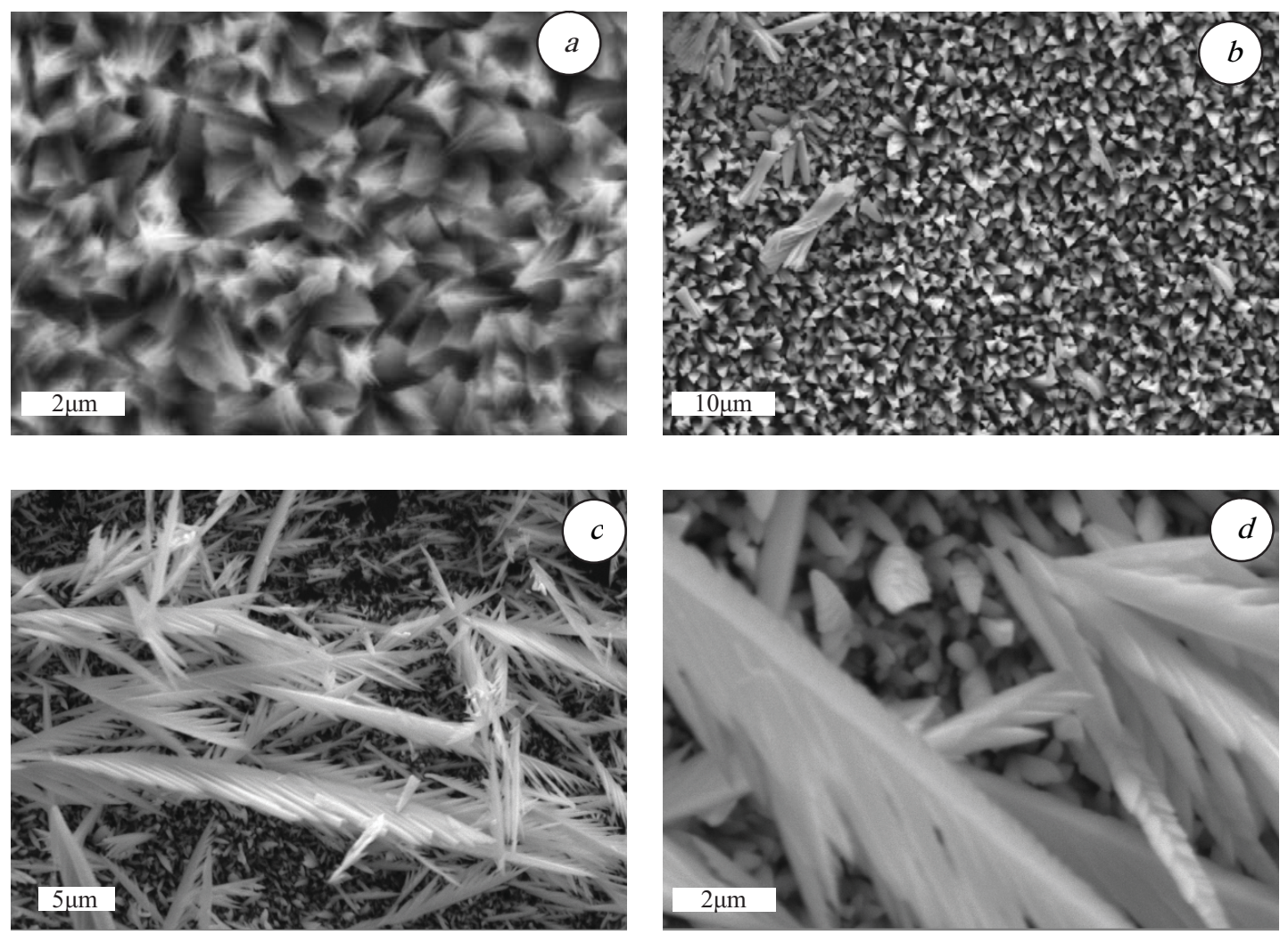

Fig. 2. SEM image of cathode tellurium obtained in $0.05 \mathrm{M} \mathrm{TeCl}_{4}$ in DMF at $313 \mathrm{~K}$ and potentials (V): $-1.0(\mathrm{a}) ;-1.1$ (b); -1.25 (c, d) 

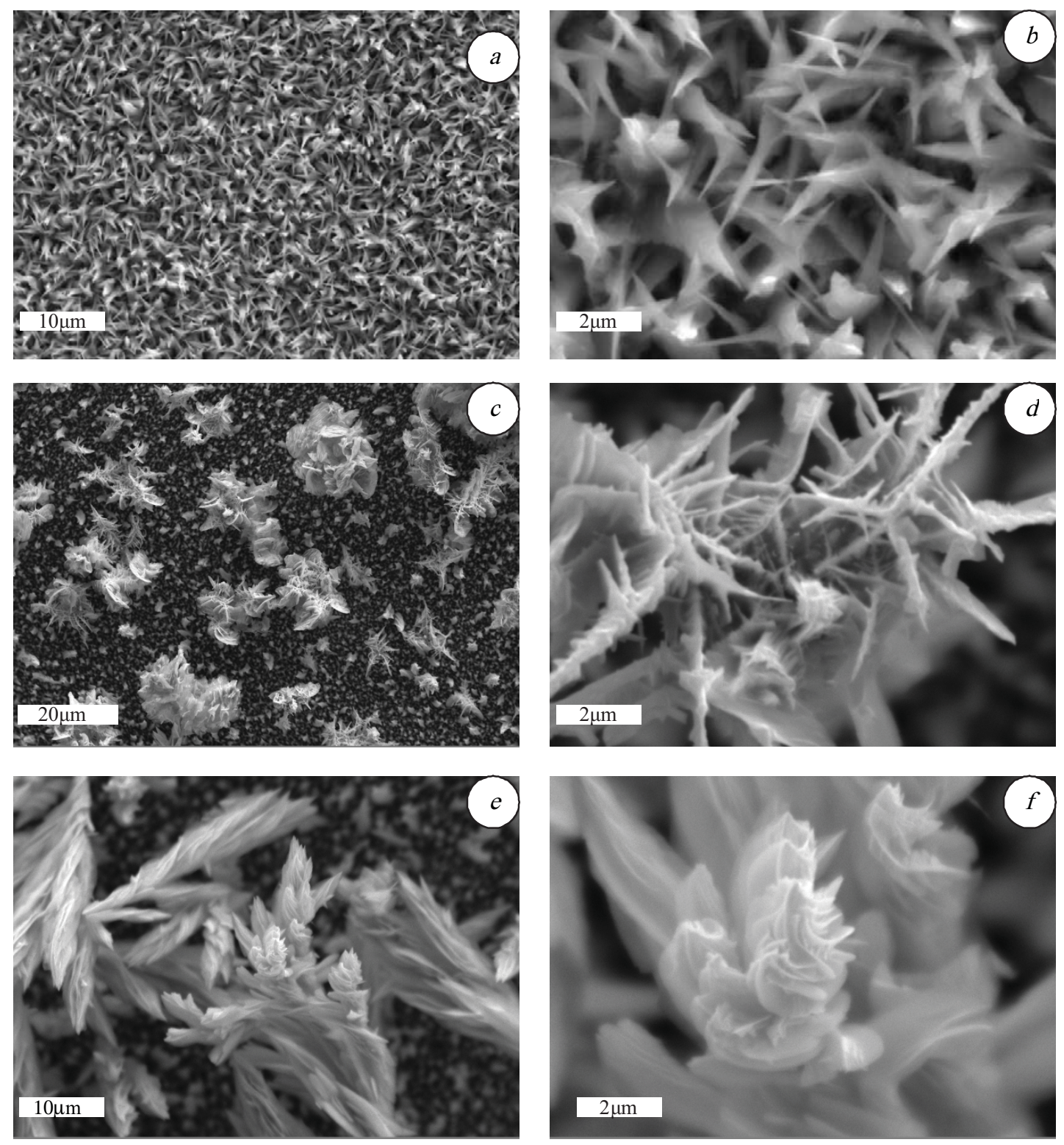

Fig. 3. SEM image of cathode tellurium obtained in $0.05 \mathrm{M} \mathrm{TeCl}_{4}$ in $\mathrm{AN}$ at $313 \mathrm{~K}$ and potentials $(\mathrm{V}):-1.0(\mathrm{a}, \mathrm{b}) ;-1.5(\mathrm{c}-\mathrm{f}) 4$.

Lobes (flocks) with the thickness $\leq 0.3 \mu \mathrm{m}$ (Fig. 1d) are basic structural components. The geometry of dispersed deposit and its growth may be explained in the following way. A great amount of DMSO molecules is released at intensive electrolysis as a result of reaction (1). Surfaceactive $\mathrm{Cl}^{-}$ions are also released. Molecules of aprotic solvent and chloride-ions are localized in the place of tellurium electrochemical reduction and block the surface of crystal nucleus. Therefore, their volume growth is limited and takes place mainly in front of electrolyte.

$$
\left[\mathrm{Te}(\mathrm{DMSO})_{\mathrm{n}}\right]^{4+}+4 \mathrm{e} \rightarrow \mathrm{Te}+\mathrm{n} \cdot \mathrm{DMSO} \text {. }
$$

The tellurium deposition in dimethylformamide solutions is analogous to those in dimethylsulfoxide solutions. Thus, the compact packaging of pyramidal structural components takes place at the formation of tellurium film at low values of cathode potentials (Fig. 2a). However, the increase of cathode potential in DMF solutions of $\mathrm{TeCl}_{4}$ in contrast to DMSO does not lead to the splicing of structural component. Consequently, the formation of glittering films does not take place. The possible reason for this is lower viscosity and therefore lower polarizing effect of DMF. At the increase of electrode potential fragments of dispersed deposit are formed over the surface of separate grains (Fig. 2b). Then they form dispersed deposit in the form of feathers with the thickness $\leq 0.2 \mu \mathrm{m}$ (Figs. $2 \mathrm{c}$ and $2 \mathrm{~d}$ ). 
Tellurium structural components obtained in AN by electrolysis using compact deposit mode have spinous form with thickness $\leq 0.2 \mu \mathrm{m}$ (Figs. $3 \mathrm{a}$ and $3 \mathrm{~b}$ ). So, nanoparticles are formed already at the stage of films deposition. With the increase of electrodes potential dispersed agglomerates with plate thickness $\leq 0.1 \mu \mathrm{m}$ are being formed and further reshaped to scroll (Figs. $3 \mathrm{c}$ and 3d) or spiral (Figs. 3e and 3f) conglomerates.

Such a difference in morphology of cathode deposits may be explained by different cathode polarization of tellurium in the used solvents [7]. Donor numbers of DMSO and DMF are characterized by approximately identical values, whereas donor number of AN is much less (29.8, 27.0 and 14.1, correspondingly). The solvent viscosity decreases essentially in the raw DMSO, DMF and AN. The cathode polarization has the greatest value in DMSO solution of $\mathrm{TeCl}_{4}$ and the lowest value in $\mathrm{AN}$ solution. Electrochemical deposition of dispersed deposit is an unstable process. It is connected, first of all, with constant change of cathode area, as well as with the change of current density $\left(\mathrm{i}_{\mathrm{c}}\right)$ and cathode concentration of metal ions. In our case these destabilizing factors are weakened by controlled potential electrolysis and tellurium soluble bulk anodes. At $\mathrm{E}=$ const cathode current increases proportionally to the increase of electrochemically active area of cathode. In such a way electrolysis close to the condition $i_{c}=$ const is ensured. Bulk anode due to its great area prevents the formation of boundary values of anode current $\left(i_{a}\right)$. Values of $i_{a}$ depends upon nature of aprotic solvent (L). According to the reaction (2) anode passivation takes place mainly where $\left[\mathrm{TeL}_{\mathrm{n}}{ }^{4+}\right.$ solvates are unstable.

$$
\mathrm{Te}+\mathrm{n} \cdot \mathrm{L} \rightarrow\left[\mathrm{TeL}_{\mathrm{n}}\right]^{4+}+4 \mathrm{e} .
$$

As can been seen from [7], tellurium is most sensitive to anode passivation in acetonitrile solutions and less sensitive in dimethylsulfoxide solutions.

\section{Conclusions}

1. Dispersed tellurium with nanosized particles is electrochemically deposited in $\mathrm{TeCl}_{4}$ solutions in organic aprotic solvents at relatively low values of cathode potential (from -1.25 to $-1.5 \mathrm{~V}$ ).
2. Morphology of cathode deposit depends upon medium nature. The decrease of dispersed particle sizes is accompanied by the decrease of electrodonor properties and viscosity of organic solvent.

3. Deposition stability of dispersed tellurium is ensured by controlled potential electrolysis and usage of soluble bulk anodes.

\section{Acknowledgments}

Researches using scanning microscope were carried out at scientific-technological and training center of low-temperature researches at I. Franko Lviv National University (Ukraine).

\section{References}

[1] Chen R., Xu D., Guo G. and Gui L.: Electrochimica Acta, 2004, 49, 2243.

[2] Gandhi T., Raja K.S. and Misra M.: Electrochimica Acta, 2006, 51, 5932.

[3] Heo P., Ichino R. and Okido M.: Electrochimica Acta, 2006, 51,6325 .

[4] Seop K., Cho E. and Tae A.: [in:] The proceeding of spring Symposium of Materials Research Society of Korea, 1994, 92. [5] Kuntyi O., Okhremchuk E. and Khoma M.: Mater. Sci., $2003,39,885$.

[6] Kuntyi O.: Mater. Sci., 2006, 42, 681.

[7] Huber F., Schmeisser M., Schenk P. et al.: Rukovodstvo po neorganicheskomu sintezu. Moskwa 1985.

\section{МОРФОЛОГІЯ ДИСПЕРСНОГО ТЕЛУРУ, ЕЛЕКТРОХІМІЧНО ОСАДЖЕНОГО В АПРОТОННИХ РОЗЧИННИКАХ}

Анотація. Досліджено електроліз розчинів $\mathrm{TeCl}_{4} 6$ диметилсульфоксиді, диметилформаміді та ацетонітрилі 3 використанням розчинних телурових анодів. У $0.05 \mathrm{M} \mathrm{TeCl}_{4}$ за 313 К на графітовій підкладиі при потенціалах менше ніж $1.0 \mathrm{~V}$ спостерігається формування компактного телурового осаду, при потенціалах більше ніж 1.25-1.5 V-дисперсного телуру. За даними досліджень за допомогою растрової мікроскопії встановлено, що дисперсний телур формується у конгломерати, що містять пелюстко - $і$ пір 'яподібні утворення товщиною 0.3-0.1 $\mu \mathrm{m}$.

Ключові слова: осадження телуру, морфологія, електроліз, апротонні розчинники 